\title{
Article \\ Effect of the Addition of Milk Protein Preparations on Selected Quality Parameters and Nutritional Characteristics of Kefir
}

\author{
Małgorzata Ziarno ${ }^{1, *(\mathbb{D}}$, Rozeta Hasalliu ${ }^{2}$ and Angelika Cwalina ${ }^{1}$ \\ 1 Department of Food Technology and Assessment, Division of Milk Technology, Institute of Food Science, \\ Warsaw University of Life Sciences-SGGW (WULS-SGGW), 02-787 Warsaw, Poland; \\ cwalinaangelika@wp.pl \\ 2 Faculty of Biotechnology and Food, Agricultural University of Tirana, 1029 Tirana, Albania; \\ hasalliur@yahoo.com \\ * Correspondence: malgorzata_ziarno@sggw.edu.pl; Tel.: +48-225937666
}

Citation: Ziarno, M.; Hasalliu, R.; Cwalina, A. Effect of the Addition of Milk Protein Preparations on Selected Quality Parameters and Nutritional Characteristics of Kefir. Appl. Sci. 2021, 11, 966. https://doi.org/ 10.3390/app11030966

Academic Editor: Maria Kanellaki

Received: 6 January 2021

Accepted: 19 January 2021

Published: 21 January 2021

Publisher's Note: MDPI stays neutral with regard to jurisdictional claims in published maps and institutional affiliations.

Copyright: (c) 2021 by the authors. Licensee MDPI, Basel, Switzerland. This article is an open access article distributed under the terms and conditions of the Creative Commons Attribution (CC BY) license (https:// creativecommons.org/licenses/by/ $4.0 /)$.

\begin{abstract}
The aim of this study was to evaluate the effect of the addition of various milk protein powder preparations (MPC-80, WPC-70, sweet whey, non-demineralized or demineralized whey, whey permeate, rennet casein, buttermilk) to selected quality parameters and digestibility of milk proteins in kefir. Kefir samples analyzed in the study were prepared under laboratory conditions with three industrial bacterial starter cultures. They were examined microbiologically (lactobacilli, lactococci, yeast) and for $\mathrm{pH}$, total protein content, hardness, adhesiveness, water-holding capacity (WHC), and protein digestibility (using two in vitro methods along with the determination of the content of available lysine and glycine). The counts of lactococci and lactobacilli were estimated at levels above 7 and $6 \log (\mathrm{CFU} / \mathrm{mL})$, respectively. Yeast was not found in the kefir samples. The $\mathrm{pH}$ value of the samples was 4.4-5.2. The $\mathrm{pH}$, hardness, adhesiveness, and WHC were dependent on the type of kefir starter culture and the type of milk protein powder added. Each protein preparation added increased the amount of available lysine and glycine. However, when converted for $1 \mathrm{~g}$ of kefir protein, the changes in the content of available lysine and glycine were variable and depended on both the milk protein powder and starter culture used.
\end{abstract}

Keywords: fermented milks; kefir starter culture; hardness; adhesiveness; milk proteins digestibility; milk protein; whey protein; casein; buttermilk

\section{Introduction}

Kefir is fermented milk, traditionally made using cow's milk or goat's milk, originated from parts of Eastern Europe and Southwest Asia, which is usually produced using kefir grains or starter cultures containing the microflora that are necessary for carrying out lactic and alcoholic fermentation characteristic of kefir formation (i.e., lactobacilli, lactococci, yeasts, or sometimes acetic acid bacteria) [1-3]. Kefir regulations vary worldwide. Traditional kefir, made by adding kefir grains to milk, contains yeast (lactose fermenting yeasts such as Kluyveromyces marxianus, and non-lactose-fermenting yeasts such as Saccharomyces unisporus, Saccharomyces cerevisiae, and Saccharomyces exiguus) and lactic acid bacteria (mainly lactobacilli, but also Leuconostoc, Lactococcus, and Acetobacter growing in a strong specific relationship). Modern kefir-like fermented milks, obtained by applying kefir starter cultures, does not always contain yeast (or it contains only selected yeast groups, for example that ferment lactose such as Kluyveromyces marxianus, or do not ferment lactose, such as Saccharomyces), and it can contain only lactic acid bacteria. The technology used for the production of fermented milk involves the use of various additives for processing milk which improves the textural, sensory, and nutritional properties of the final products. In addition to the use of skimmed milk powder (SMP) or concentration of the processing milk in a vacuum evaporator, other forms of milk proteins, such as milk protein concentrates (MPCs) or whey protein concentrates (WPCs) are used to increase the solid content of the 
milk base. Each of these additives produces a different effect on the quality and nutritional characteristics of fermented milk. For example, WPC has a higher biological value than SMP and stimulates the growth of several strains of lactic acid bacteria [4].

Kefir contains essential amino acids and easily digestible proteins, which when digested help the body to maintain its functions [5]. In recent decades, several innovative kefir drinks have been introduced, including those enriched with ingredients such as milk proteins which render the drink with specific and valuable properties [6-8]. The nutritional characteristics of kefir are related to the bioavailability of its ingredients. Bioavailability refers to the degree to which a nutrient has been released and absorbed from the digestive system and used by the human body. Digestibility in turn is related to bioavailability which refers to the susceptibility of products or nutrients to the activity of digestive enzymes. The digestibility of a food product is determined by its ingredients, including proteins, carbohydrates, and fats, or the food as a whole $[9,10]$. It is assessed by calculating the coefficients of the digestive process of a human or animal organism-digestion in vivo-or by testing the level of the enzymatic hydrolysis of meals under laboratory conditions-digestion in vitro [9-14].

This study aimed to evaluate the effects of the addition of various forms of milk proteins, including MPC, WPC, demineralized or non-demineralized whey, sweet whey, whey permeate, rennet casein, and buttermilk powders, on selected quality parameters and the digestibility of milk proteins in kefir. In addition, the study compared two methods applied for determining the digestibility of milk proteins using in vitro enzymatic digestion.

\section{Materials and Methods}

\subsection{Materials}

Kefir Starter Cultures. Three industrial bacterial starter cultures were used in this study: Kefir A-“Zakwaska do kefiru“ (GAMA-TECH Leszek Marek Krześniak, Warsaw, Poland), mesophilic kefir culture containing Lactococcus lactis, Streptococcus thermophilus, Leuconostoc mesenteroides, and Lactobacillus acidophilus (or) Bifidobacterium lactis, Lactobacillus delbrueckii subsp. bulgaricus, and L. lactis subsp. lactis; Kefir B-“"VIVO" (GAMA-TECH Leszek Marek Krześniak, Warsaw, Poland), mesophilic kefir culture containing L. lactis, S. thermophilus, L. mesenteroides, and L. acidophilus (or) B. lactis, L. delbrueckii subsp. bulgaricus, S. thermophilus, and L. lactis subsp. lactis; Kefir C-Choozit Kefilmild 01 (DuPont Danisco, Copenhagen, Denmark), mesophilic kefir culture containing L. lactis subsp. lactis, L. lactis subsp. cremoris, L. lactis subsp. lactis biovar. diacetylactis, L. mesenteroides subsp. mesenteroides, S. thermophilus, and L. acidophilus.

Milk Protein Powders. Eight commercial milk protein powders were used in this study: (1) MPC-80 (Hoogwegt Poland, Warsaw, Poland), MPC powder with a declared milk protein content of 80\%; (2) WPC-70 (Mlekovita, Wysokie Mazowieckie, Poland), demineralized WPC powder with a declared whey protein content of $70 \%$; (3) demineralized whey powder (AgroComplex, Wyszków, Poland) preparation with a declared protein content of $80 \%$; (4) non-demineralized whey powder (Promar, Zawiercie, Polska) preparation with a declared protein content of 65\%; (5) sweet whey powder 6\% (AgroComplex, Wyszków, Poland), rennet whey powder preparation with a declared protein content of 6\%; (6) whey permeate powder (Arla Foods Ingredients Group P/S, Viby, Denmark) preparation with a declared protein content of 3\%; (7) rennet casein powder (Promar, Zawiercie, Polska) preparation with a declared protein content of $90 \%$; and (8) buttermilk powder (OSM Łowicz, Łowicz, Poland) with a declared protein content of $11 \%$.

\subsection{Preparation of Kefir Samples}

In the experiment, pasteurized cow milk "Łowickie" (OSM Łowicz, Łowicz, Poland) with a fat content of $2.0 \%$ was used. Milk protein preparations were added at an amount of $6 \mathrm{wt}$ \% to a $1000-\mathrm{g}$ portion of milk at $25^{\circ} \mathrm{C}$. The powders were thoroughly mixed in milk for 15 min with a laboratory homogenizing mixer (Silverson L4R, Silverson Machines Ltd., Chesham, England) and left for approximately $20 \mathrm{~min}$ at $25^{\circ} \mathrm{C}$ to hydrate the preparations 
and to allow swelling of the proteins contained in them. Then, the milk samples were poured into sterile glass jars (170 g each), sealed, and fermented at $25^{\circ} \mathrm{C}$ for $24 \mathrm{~h}$. After fermentation, the $\mathrm{pH}$ of the samples was measured to ensure the correctness of the process, and the samples were stored at $4^{\circ} \mathrm{C}$ for 1 day before all analyses were performed. The experiment was performed twice.

\subsection{Microbiological Analysis}

Microbiological analysis was performed by the traditional plate method [15], according to the following standards: ISO 15214:1998 [16] and ISO 6611:2004 [17]. The number of each type of bacteria was determined with three repetitions. The following microbiological media were used for the analyses: MRS (de Man, Rogosa, and Sharpe) agar (Merck, Darmstadt, Germany), for determining the number of lactobacilli cells; M17 agar (Merck, Darmstadt, Germany), for determining the number of lactococci cells; and YGC (Yeast Extract Glucose Chloramphenicol) agar (Merck, Darmstadt, Germany), for determining the number of yeasts. All media were incubated at $30{ }^{\circ} \mathrm{C}$ for $72 \mathrm{~h}$. The Petri dishes with the MRS agar were inserted in the anaerobic jars (Merck, Darmstadt, Germany), those containing the M17 agar were grown aerobically, and Petri dishes with the YGC agar were incubated aerobically for up to 5 days at $25^{\circ} \mathrm{C}$. The results are expressed as mean values of colony-forming unit per $\mathrm{mL}$ of kefir sample $(\mathrm{CFU} / \mathrm{mL})$ in two parallel replicates, and then as decadic logarithm.

\subsection{Determination of the $\mathrm{pH}$ Value}

The $\mathrm{pH}$ value was measured in well-mixed kefir samples using a CPO-505 digital $\mathrm{pH}-$ meter (Elmetron, Zabrze, Poland) calibrated at $25^{\circ} \mathrm{C}$ with temperature compensation [18]. The measurements were made in three repetitions for each type of sample.

\subsection{Texture Analysis}

Hardness and adhesiveness of the kefir samples were analyzed using the method described by Ziarno and Zaręba [18]. A Brookfield CT3 10 K Texture Analyzer (Brookfield Engineering Laboratories Inc., Middleborough, MA, USA) was used for the analyses. During the analysis, the samples were not removed from the containers. A TA4/1000 probe (cylinder, $38.1 \mathrm{~mm} \mathrm{D}$, and $20 \mathrm{~mm} \mathrm{~L}$ ) was used to determine the texture profile of samples (in triplicate) in $170-\mathrm{mL}$ cups at $4{ }^{\circ} \mathrm{C}$. The samples were compressed by $30 \mathrm{~mm}$, with a trigger force of $4.5 \mathrm{~g}$. The speed of the probe was fixed at $1 \mathrm{~mm} / \mathrm{s}$ during the pretest compression and relaxation of the samples. In accordance with the manufacturer's instructions, hardness was defined as the force necessary to attain a given deformation (the maximal peak value recorded after the first immersion into the sample), while adhesiveness was expressed as the work necessary to break probe from the sample area (a product of the force necessary for emerging the probe from the sample and time).

\subsection{Determination of Water-Holding Capacity (WHC)}

The WHC of the kefir samples was determined using the method described by Ziarno and Zaręba [18]. Briefly, $15.00 \mathrm{~g}$ of the kefir samples was centrifuged at $3250 \mathrm{~g}$ for $10 \mathrm{~min}$ at $4{ }^{\circ} \mathrm{C}$. Then, the supernatant was collected and weighed with an accuracy of two decimal places. WHC was calculated as follows: WHC $(\%)=(\mathrm{m} 1 / \mathrm{m} 2) \times 100$, where $\mathrm{m} 1$ is the mass of precipitate after centrifugation $(\mathrm{g})$ and $\mathrm{m} 2$ is the mass of the kefir sample $(\mathrm{g})$. All the experiments were repeated three times.

\subsection{Determination of Protein Content}

Protein content was determined according to the standard ISO 89684:2016, Milk and milk products-Determination of nitrogen content-Part 4: Determination of protein and non-protein nitrogen content and true protein content calculation (reference method) [19]. 


\subsection{Determination of Protein Digestibility}

Protein digestibility was determined using two methods. The first method was described by Hęs et al. [11]. The principle of this method is to determine the content of free lysine which in turn is used to assess the digestibility of protein [11]. Available lysine was determined using the method of Hall et al. [20]. The content of available lysine was expressed as mg per $100 \mathrm{~g}$ of protein. The analysis was carried out in three repetitions for each kefir sample.

The second method was described by Pokorska-Lis et al. [12,21]. Briefly, the principle of the method consists in subjecting the test samples to a two-step enzymatic hydrolysis process (first pepsin digestion in a hydrochloric acid environment and then trypsin digestion in a slightly alkaline environment) followed by spectrophotometric determination of the concentration of available glycine (reaction with ninhydrin) against a standard curve. The colored product formed from the reaction with ninhydrin was determined spectrophotometrically at a wavelength of $570 \mathrm{~nm}$. The concentration of available glycine was calculated based on the standard curve [12,22]. The content of available glycine was expressed as mg per $100 \mathrm{~g}$ of product. The analysis was carried out in three repetitions for each kefir sample.

\subsection{Statistical Analysis of Results}

The results were statistically analyzed in Statgraphics XVII program (Statgraphics Technologies, Inc., The Plains, VA, USA), using multivariate analysis of variance and Tukey's test $(\alpha=0.05)$.

\section{Results}

\subsection{Starter Microflora Population}

The number of Lactococcus spp. in the kefir samples ranged from 7.8 to $9.2 \log (\mathrm{CFU} / \mathrm{mL})$ (Table 1). The type of kefir starter culture and milk protein powder used had a statistically significant effect on the Lactococcus spp. population ( $p=0.001$ in both cases). On the other hand, this population was not influenced by the final $\mathrm{pH}$ of kefirs $(p=0.3761)$. The number of lactobacilli in the kefir samples ranged from 6.8 to $8.2 \log (\mathrm{CFU} / \mathrm{mL})$ (Table 1). As observed for lactococci, the number of lactobacilli depended on the type of starter culture and milk powder used as an additive ( $p=0.001$ in both cases). The effect of the final $\mathrm{pH}$ of kefir samples on the number of these bacteria in kefir was also not found to be statistically significant $(p=0.3669)$. However, it is worth noting that the lactobacilli count was generally lower than the number of lactococcal cells. The presence of yeast was not observed at a dilution of $10^{-3}$ in any of the samples analyzed.

Table 1. Value of $\mathrm{pH}$ and lactic acid bacteria count in kefir samples (mean and standard deviation calculated from six repetitions).

\begin{tabular}{|c|c|c|c|}
\hline $\begin{array}{c}\text { Kefir Samples with the Addition of Milk } \\
\text { Powder }\end{array}$ & $\mathrm{pH}$ & $\begin{array}{l}\text { Lactococci Population } \\
\quad(\log (\text { CFU } / \mathrm{mL}))\end{array}$ & $\begin{array}{l}\text { Lactobacilli Population } \\
\quad(\log (\mathrm{CFU} / \mathrm{mL}))\end{array}$ \\
\hline \multicolumn{4}{|c|}{ Kefir A } \\
\hline control & $4.4 \pm 0.2^{\mathrm{f}}$ & $8.8 \pm 0.0^{\mathrm{a}, \mathrm{b}}$ & $7.8 \pm 0.0^{\mathrm{a}, \mathrm{b}}$ \\
\hline MPC-80 & $5.1 \pm 0.1^{\mathrm{a}}$ & $9.2 \pm 0.0^{\mathrm{a}}$ & $8.2 \pm 0.0^{\mathrm{a}}$ \\
\hline WPC-70 & $5.1 \pm 0.1^{\mathrm{a}}$ & $8.2 \pm 0.1^{\mathrm{d}}$ & $7.2 \pm 0.1^{\mathrm{d}}$ \\
\hline rennet casein & $5.1 \pm 0.1^{\mathrm{a}}$ & $8.9 \pm 0.1^{\mathrm{a}}$ & $7.9 \pm 0.1^{\mathrm{a}}$ \\
\hline sweet whey powder & $4.7 \pm 0.2^{\mathrm{d}}$ & $8.8 \pm 0.1^{\mathrm{a}, \mathrm{b}}$ & $7.8 \pm 0.1^{\mathrm{a}, \mathrm{b}}$ \\
\hline whey permeate powder & $4.7 \pm 0.2^{\mathrm{d}, \mathrm{e}}$ & $8.8 \pm 0.1^{\mathrm{a}, \mathrm{b}}$ & $7.8 \pm 0.1^{\mathrm{a}, \mathrm{b}}$ \\
\hline whey powder (demineralized) & $4.7 \pm 0.2^{\mathrm{e}}$ & $8.8 \pm 0.0^{\mathrm{a}, \mathrm{b}}$ & $7.8 \pm 0.0^{\mathrm{a}, \mathrm{b}}$ \\
\hline whey powder (non-demineralized) & $4.6 \pm 0.2^{\mathrm{e}}$ & $8.6 \pm 0.1 \mathrm{~b}$ & $7.6 \pm 0.1^{b, c}$ \\
\hline buttermilk powder & $4.6 \pm 0.2^{\mathrm{e}, \mathrm{f}}$ & $8.9 \pm 0.2^{a}$ & $7.9 \pm 0.2^{a}$ \\
\hline
\end{tabular}


Table 1. Cont.

\begin{tabular}{|c|c|c|c|}
\hline $\begin{array}{c}\text { Kefir Samples with the Addition of Milk } \\
\text { Powder }\end{array}$ & $\mathrm{pH}$ & $\begin{array}{l}\text { Lactococci Population } \\
\quad(\log (\mathrm{CFU} / \mathrm{mL}))\end{array}$ & $\begin{array}{l}\text { Lactobacilli Population } \\
\quad(\log (\mathrm{CFU} / \mathrm{mL}))\end{array}$ \\
\hline \multicolumn{4}{|c|}{ Kefir B } \\
\hline control & $4.7 \pm 0.2^{\mathrm{e}}$ & $8.7 \pm 0.1^{\mathrm{a}, \mathrm{b}, \mathrm{c}}$ & $7.7 \pm 0.1^{\mathrm{b}, \mathrm{c}}$ \\
\hline MPC-80 & $5.1 \pm 0.1^{\mathrm{a}, \mathrm{b}}$ & $7.8 \pm 0.3^{\mathrm{e}}$ & $6.8 \pm 0.3^{\mathrm{e}}$ \\
\hline WPC-70 & $5.1 \pm 0.1^{\mathrm{a}, \mathrm{b}}$ & $8.3 \pm 0.2^{\mathrm{d}, \mathrm{e}}$ & $7.3 \pm 0.2^{\mathrm{d}}$ \\
\hline rennet casein & $5.2 \pm 0.1^{\mathrm{a}}$ & $8.8 \pm 0.4^{\mathrm{a}, \mathrm{b}}$ & $7.8 \pm 0.4^{\mathrm{a}, \mathrm{b}}$ \\
\hline sweet whey powder & $4.8 \pm 0.2^{\mathrm{c}}$ & $8.4 \pm 0.1^{\mathrm{c}, \mathrm{d}}$ & $7.4 \pm 0.1^{\mathrm{c}}$ \\
\hline whey permeate powder & $4.7 \pm 0.2^{\mathrm{d}}$ & $9.1 \pm 0.0^{\mathrm{a}}$ & $8.1 \pm 0.0^{\mathrm{a}}$ \\
\hline whey powder (demineralized) & $4.8 \pm 0.2^{\mathrm{c}}$ & $9.1 \pm 0.0^{\mathrm{a}}$ & $8.1 \pm 0.0^{\mathrm{a}}$ \\
\hline whey powder (non-demineralized) & $4.8 \pm 0.2^{\mathrm{c}}$ & $8.8 \pm 0.0^{\mathrm{a}, \mathrm{b}}$ & $7.8 \pm 0.0^{\mathrm{a}, \mathrm{b}}$ \\
\hline buttermilk powder & $4.8 \pm 0.2^{\mathrm{c}}$ & $8.5 \pm 0.1^{c}$ & $7.5 \pm 0.1^{b}$ \\
\hline \multicolumn{4}{|c|}{ Kefir C } \\
\hline control & $4.3 \pm 0.2^{g}$ & $9.0 \pm 0.1^{\mathrm{a}}$ & $8.0 \pm 0.1^{\mathrm{a}}$ \\
\hline MPC-80 & $4.9 \pm 0.2^{b}$ & $8.9 \pm 0.1^{\mathrm{a}}$ & $7.9 \pm 0.1^{\mathrm{a}}$ \\
\hline WPC-70 & $5.1 \pm 0.1^{\mathrm{a}}$ & $9.2 \pm 0.0^{\mathrm{a}}$ & $8.2 \pm 0.0^{\mathrm{a}}$ \\
\hline rennet casein & $4.8 \pm 0.2^{\mathrm{d}}$ & $8.4 \pm 0.6^{\mathrm{c}, \mathrm{d}}$ & $7.4 \pm 0.6^{c}$ \\
\hline sweet whey powder & $4.5 \pm 0.2^{f}$ & $9.2 \pm 0.1^{\mathrm{a}}$ & $8.1 \pm 0.1^{\mathrm{a}}$ \\
\hline whey permeate powder & $4.5 \pm 0.2^{f}$ & $9.1 \pm 0.0^{\mathrm{a}}$ & $8.1 \pm 0.0^{\mathrm{a}}$ \\
\hline whey powder (demineralized) & $4.4 \pm 0.2^{\mathrm{f}}$ & $9.1 \pm 0.0^{\mathrm{a}}$ & $8.1 \pm 0.0^{\mathrm{a}}$ \\
\hline whey powder (non-demineralized) & $4.5 \pm 0.2^{f}$ & $9.1 \pm 0.0^{\mathrm{a}}$ & $8.1 \pm 0.0^{\mathrm{a}}$ \\
\hline buttermilk powder & $4.4 \pm 0.2^{f}$ & $9.1 \pm 0.0^{\mathrm{a}}$ & $8.1 \pm 0.0^{\mathrm{a}}$ \\
\hline
\end{tabular}

${ }^{a-g}$ the same letter indices within the same column do not mean statistically significant differences at the significance level of 0.05 .

\subsection{Acidity of Kefir Samples}

The $\mathrm{pH}$ of milk significantly decreased $(p<0.05)$ after $24 \mathrm{~h}$ of fermentation with all kefir starters, although not all kefir samples were characterized by similar $\mathrm{pH}$ values. Statistical analysis showed that the $\mathrm{pH}$ value of the kefir samples significantly depended on the type of starter culture and milk protein powder used ( $p=0.001$ in both cases). In general, kefir $\mathrm{C}$ samples had lower $\mathrm{pH}$ values (average 4.6) than kefir A (average 4.8) and kefir B (average 4.9), and the samples prepared with WPC-70 (average 5.1), MPC-80 (average 5.1), or rennet casein powder (average 5.0) had a higher $\mathrm{pH}$ than the other kefir samples (average 4.6).

\subsection{Texture Analysis of Kefir Samples}

The hardness of kefirs prepared with milk protein powders was significantly different from that of the control sample (Table 2 ) and was statistically significantly influenced by the type of powder added as well as starter culture used for milk fermentation $(p=0.001$ for both factors). In general, the lowest mean values of hardness were observed for kefir B samples, while the highest values were noted for kefir $C$ samples. The significant influence of the starter culture used for milk fermentation on the hardness of the obtained kefir samples proved that with the addition of different milk protein powders, the hardness of kefirs differs. For kefir A, the highest hardness was noted in the samples prepared with buttermilk powder $(1.98 \mathrm{~N})$, while the samples prepared with sweet whey powder, whey permeate powder, and demineralized or non-demineralized whey powder had a lower hardness than the control samples $(0.64,0.73,0.87,1.07$, and $1.35 \mathrm{~N}$, respectively). However, it should be noted that different cultures resulted in different kefir texture properties on their own. This can be seen, for example, analyzing the results of the control samples. Kefir A control samples were characterized by significantly higher hardness (average $1.35 \pm$ $0.04 \mathrm{~N}$ ) than the control kefir samples B and C (average $0.65 \pm 0.02 \mathrm{~N}$ and $0.96 \pm 0.03 \mathrm{~N}$, respectively). 
Table 2. Physicochemical parameters of the kefir samples tested (mean and standard deviation calculated from six repetitions).

\begin{tabular}{|c|c|c|c|c|}
\hline $\begin{array}{l}\text { Kefir Samples with the Addition of } \\
\text { Milk Powder }\end{array}$ & Protein Content (\%) & WHC (\%) & Hardness (N) & Adhesiveness (mJ) \\
\hline \multicolumn{5}{|c|}{ Kefir A } \\
\hline control & $3.1 \pm 0.1^{\mathrm{f}}$ & $63.9 \pm 0.4^{1}$ & $1.35 \pm 0.04^{\mathrm{f}}$ & $7.60 \pm 0.38^{c}$ \\
\hline MPC-80 & $7.7 \pm 0.1^{b}$ & $92.9 \pm 0.5^{f}$ & $1.54 \pm 0.05^{\mathrm{d}}$ & $6.40 \pm 0.32^{\mathrm{d}}$ \\
\hline WPC-70 & $7.1 \pm 0.1^{c}$ & $78.9 \pm 0.4^{j}$ & $1.72 \pm 0.05^{\mathrm{c}}$ & $6.20 \pm 0.31^{d}$ \\
\hline rennet casein & $8.3 \pm 0.2^{\mathrm{a}}$ & $87.1 \pm 0.5^{\mathrm{h}}$ & $1.38 \pm 0.04^{\mathrm{f}}$ & $5.70 \pm 0.29^{\mathrm{e}}$ \\
\hline sweet whey powder & $3.3 \pm 0.1^{\mathrm{f}}$ & $95.6 \pm 0.5^{\mathrm{e}}$ & $0.64 \pm 0.02^{\mathrm{i}}$ & $1.50 \pm 0.08^{\mathrm{i}}$ \\
\hline whey permeate powder & $3.2 \pm 0.2^{f}$ & $93.0 \pm 0.5^{\mathrm{f}}$ & $0.73 \pm 0.02^{j}$ & $1.00 \pm 0.05^{\mathrm{i}}$ \\
\hline whey powder (demineralized) & $7.7 \pm 0.1^{\mathrm{b}}$ & $96.2 \pm 0.5^{\mathrm{d}}$ & $0.87 \pm 0.03^{h}$ & $1.70 \pm 0.09^{h}$ \\
\hline whey powder (non-demineralized) & $6.8 \pm 0.1^{\mathrm{d}}$ & $95.7 \pm 0.5^{\mathrm{d}, \mathrm{e}}$ & $1.07 \pm 0.03 \mathrm{~g}$ & $1.90 \pm 0.10^{g}$ \\
\hline buttermilk powder & $3.6 \pm 0.1^{\mathrm{e}}$ & $98.2 \pm 0.5^{b}$ & $1.98 \pm 0.06^{b}$ & $7.90 \pm 0.40^{c}$ \\
\hline \multicolumn{5}{|c|}{ Kefir B } \\
\hline control & $3.1 \pm 0.1^{\mathrm{f}}$ & $66.1 \pm 0.4^{1}$ & $0.65 \pm 0.02^{a, j}$ & $1.60 \pm 0.08^{h}$ \\
\hline MPC-80 & $7.7 \pm 0.1^{b}$ & $93.6 \pm 0.5^{f}$ & $1.76 \pm 0.05^{c}$ & $10.70 \pm 0.54^{\mathrm{a}}$ \\
\hline WPC-70 & $7.1 \pm 0.1^{c}$ & $76.9 \pm 0.4^{j}$ & $0.64 \pm 0.02^{j}$ & $0.50 \pm 0.03^{\mathrm{j}}$ \\
\hline rennet casein & $8.3 \pm 0.1^{\mathrm{a}}$ & $86.9 \pm 0.5^{h}$ & $1.46 \pm 0.04^{\mathrm{e}}$ & $7.60 \pm 0.38^{c}$ \\
\hline sweet whey powder & $3.2 \pm 0.2^{f}$ & $96.0 \pm 0.5^{\mathrm{d}}$ & $0.61 \pm 0.02^{j}$ & $2.20 \pm 0.11 \mathrm{~g}$ \\
\hline whey permeate powder & $3.2 \pm 0.2^{f}$ & $89.4 \pm 0.5 \mathrm{~g}$ & $0.60 \pm 0.02^{j}$ & $2.20 \pm 0.11 \mathrm{~g}$ \\
\hline whey powder (demineralized) & $7.7 \pm 0.1^{b}$ & $96.7 \pm 0.5^{\mathrm{d}}$ & $0.88 \pm 0.03^{h, i}$ & $3.60 \pm 0.18^{f}$ \\
\hline whey powder (non-demineralized) & $6.8 \pm 0.1^{\mathrm{d}}$ & $97.4 \pm 0.5^{c}$ & $0.91 \pm 0.03^{h}$ & $3.10 \pm 0.16^{f}$ \\
\hline buttermilk powder & $3.6 \pm 0.1^{\mathrm{e}}$ & $99.0 \pm 0.5^{\mathrm{a}}$ & $1.43 \pm 0.04 \mathrm{e}^{\mathrm{e}}$ & $8.70 \pm 0.44^{b}$ \\
\hline \multicolumn{5}{|c|}{ Kefir C } \\
\hline control & $3.1 \pm 0.1^{\mathrm{f}}$ & $60.6 \pm 0.3^{1}$ & $0.96 \pm 0.03^{\mathrm{h}}$ & $3.00 \pm 0.15^{\mathrm{f}}$ \\
\hline MPC-80 & $7.7 \pm 0.2^{b}$ & $95.3 \pm 0.5^{\mathrm{e}}$ & $1.62 \pm 0.05^{\mathrm{a}}$ & $7.20 \pm 0.36^{c, d}$ \\
\hline WPC-70 & $7.1 \pm 0.1^{c}$ & $77.0 \pm 0.4^{j}$ & $2.44 \pm 0.07^{\mathrm{d}}$ & $3.00 \pm 0.15^{\mathrm{f}}$ \\
\hline rennet casein & $8.3 \pm 0.2^{\mathrm{a}}$ & $76.6 \pm 0.4^{\mathrm{k}}$ & $1.32 \pm 0.04^{f}$ & $8.20 \pm 0.41^{b}$ \\
\hline sweet whey powder & $3.3 \pm 0.1^{\mathrm{f}}$ & $92.9 \pm 0.5^{f}$ & $0.81 \pm 0.02^{\mathrm{i}}$ & $1.60 \pm 0.08^{h}$ \\
\hline whey permeate powder & $3.2 \pm 0.2^{f}$ & $83.6 \pm 0.5^{\mathrm{i}}$ & $0.81 \pm 0.02^{\mathrm{i}}$ & $1.10 \pm 0.06^{\mathrm{i}}$ \\
\hline whey powder (demineralized) & $7.7 \pm 0.1^{b}$ & $93.2 \pm 0.5^{\mathrm{f}}$ & $1.18 \pm 0.04 \mathrm{~g}$ & $1.90 \pm 0.10^{g}$ \\
\hline whey powder (non-demineralized) & $6.8 \pm 0.1^{\mathrm{d}}$ & $94.8 \pm 0.5^{\mathrm{e}}$ & $1.34 \pm 0.04^{\mathrm{f}}$ & $2.70 \pm 0.14 \mathrm{~g}$ \\
\hline buttermilk powder & $3.6 \pm 0.1^{\mathrm{e}}$ & $97.9 \pm 0.5^{c}$ & $2.16 \pm 0.06^{\mathrm{a}}$ & $7.20 \pm 0.36^{c, d}$ \\
\hline
\end{tabular}

${ }^{a-1}$ the same letter indices within the same column do not mean statistically significant differences at the significance level of 0.05 .

In the case of kefir B, the highest hardness was found for samples prepared with MPC-80 powder $(1.17 \mathrm{~N})$, while the lowest for control samples $(0.65 \mathrm{~N})$ and samples prepared with WPC-70 powder $(0.64 \mathrm{~N})$, sweet whey powder $(0.61 \mathrm{~N})$, and whey permeate powder $(0.60 \mathrm{~N})$. For kefir $\mathrm{C}$, the highest hardness values were recorded for the samples prepared with WPC-70 $(2.44 \mathrm{~N})$ and buttermilk powder $(2.16 \mathrm{~N})$, and the lowest for samples containing sweet whey powder $(0.81 \mathrm{~N})$ or whey permeate powder $(0.81 \mathrm{~N})$. It follows that in each case, kefir prepared with sweet whey powder or whey permeate powder had the lowest hardness values, which were comparable to the control samples or even lower than them. The hardness value did not depend on the $\mathrm{pH}$ of the kefir samples $(p=0.4745)$. Of course, it should be noted that this could be more accurately determined by adjusting the acidity of the same samples to different $\mathrm{pH}$ values. This needs to be explored further in future.

The adhesiveness of kefirs prepared with milk protein powders differed statistically significantly from each other and depended both on the type of the added milk protein powder and starter culture used ( $p=0.001$ in both cases). It should be noted that different cultures resulted in different adhesiveness value of kefirs. This can be seen, for example, analyzing the results of the control samples. Kefir A control samples were characterized by significantly higher adhesiveness (average $7.60 \pm 0.38 \mathrm{~mJ}$ ) than the control kefir samples $\mathrm{B}$ and C (average $1.60 \pm 0.08 \mathrm{~mJ}$ and $3.00 \pm 0.15 \mathrm{~mJ}$, respectively). Further analysis of samples containing the addition of various milk protein preparations allows to notice other dependencies, considering the total effect of the use of different stack cultures and the addition of different milk proteins. Kefir A and B samples had on average higher 
adhesiveness (mean 4.43 and $4.47 \mathrm{~mJ}$, respectively) than kefir C samples (mean $3.99 \mathrm{~mJ}$ ). However, in the case of kefir A, only samples prepared with buttermilk powder had a statistically significantly higher adhesiveness (mean $7.900 \mathrm{~mJ}$ ) than the control samples (mean $7.600 \mathrm{~mJ}$ ), while the remaining samples had lower values than the control (in a range of 1.000-6.400 mJ) (Table 2). In the case of kefir B, only samples containing rennet casein powder had lower adhesiveness values (mean $0.500 \mathrm{~mJ}$ ) than the control samples (mean $1.600 \mathrm{~mJ}$ ), while the remaining samples had higher values than the control (in a range of 2.200-10.700 mJ). In turn, among kefir C samples, those prepared with WPC-70, sweet whey powder, whey permeate powder, and demineralized or non-demineralized whey powder had lower or the same adhesiveness values as the control samples (mean $3.000 \mathrm{~mJ}$ ). On the other hand, kefir $\mathrm{C}$ samples containing rennet casein powder had the highest values of adhesiveness. It was observed that the adhesiveness value did not depend on the $\mathrm{pH}$ of the kefir samples $(p=0.5049)$.

\subsection{Water-Holding Capacity of Kefir Samples}

Total protein content influenced the WHC of kefir samples. All samples containing milk protein powders showed a higher WHC than the control kefir samples. More interestingly, the samples that had buttermilk powder had the highest WHC value $(98.2 \%, 99.0 \%$, and $97.9 \%$ for kefir A, B, and C samples, respectively). Statistical analysis showed that WHC significantly depends not only on the type of milk protein powder but also on the starter culture used ( $p=0.001$ for each of these factors). In general, we noted higher WHC values for kefir A (mean 89.1\%) and B samples (mean 89.1\%) than kefir C samples (85.8\%). We also checked whether the WHC value of the analyzed kefir samples depended on $\mathrm{pH}$, but our statistical analysis showed no such relationship $(p=0.3669)$.

\subsection{Protein Content in Kefir Samples}

We analyzed whether the hardness of kefir samples as well as their adhesiveness could be influenced by the total protein content but found no statistically significant correlations. However, we observed that the total protein content was influenced by the type of powdered milk protein preparation $(p=0.0001)$, although no significant influence was noted for the type of starter culture used $(p=0.6522)$. The highest amount of protein was contained in kefir samples prepared with rennet casein powder (mean 8.3\%, Table 2) which is rich in casein proteins. Milk protein powders rich in whey protein (WPC-70, sweet whey powder, whey permeate powder, demineralized or non-demineralized whey powder) increased the level of total protein in kefir samples to 3.2-7.7\%, depending on the type of powder used. In addition, in our experiments, we used two powders containing milk protein in general: buttermilk powder and MPC-80. In kefir samples prepared with these powders, we noted an increase in the total milk protein content to an average of 3.6\% and $7.7 \%$, respectively.

\subsection{Protein Digestibility in Kefir Samples}

Table 3 shows the content of available lysine in kefir samples prepared with the tested milk protein powders and fermented with various kefir starters (the results were expressed in terms of $1 \mathrm{~g}$ of protein and $100 \mathrm{~g}$ of kefir). In all samples, the content of available lysine was at least equal to or greater than that found in the control samples. It can be concluded that the content of available lysine in $1 \mathrm{~g}$ of protein differed statistically significantly depending on the type of milk protein preparation added and the kefir starter culture used. Based on the type of starter culture used, the kefir samples were divided into three homogeneous groups. Statistically, the highest content of available lysine was found in the kefirs obtained using starter culture $C$. 
Table 3. Digestibility test results of the tested kefirs (mean and standard deviation calculated from six repetitions).

\begin{tabular}{|c|c|c|c|c|}
\hline \multirow{2}{*}{$\begin{array}{c}\text { Kefir Samples with the Addition } \\
\text { of Milk Powder }\end{array}$} & \multicolumn{2}{|c|}{ The Concentration of Available Lysine (mg) } & \multicolumn{2}{|c|}{ The Concentration Of Available Glycine (mg) } \\
\hline & In $100 \mathrm{~g}$ of Protein & In $100 \mathrm{~g}$ of Product & In $100 \mathrm{~g}$ of Protein & In $100 \mathrm{~g}$ of Product \\
\hline \multicolumn{5}{|c|}{ Kefir A } \\
\hline control & $124 \pm 5^{g}$ & $384 \pm 16^{\mathrm{j}}$ & $28 \pm 1^{a}$ & $85 \pm 4^{\mathrm{d}, \mathrm{e}}$ \\
\hline MPC-80 & $136 \pm 1^{\mathrm{f}}$ & $1045 \pm 19^{\mathrm{e}}$ & $12 \pm 1^{\mathrm{d}}$ & $90 \pm 4^{\mathrm{d}, \mathrm{e}}$ \\
\hline WPC-70 & $171 \pm 19^{b}$ & $1214 \pm 15^{c}$ & $13 \pm 1^{\mathrm{d}}$ & $90 \pm 5^{\mathrm{d}, \mathrm{e}}$ \\
\hline rennet casein & $137 \pm 2^{\mathrm{f}}$ & $1139 \pm 19^{d}$ & $13 \pm 2^{d}$ & $110 \pm 5^{c}$ \\
\hline sweet whey powder & $155 \pm 15^{\mathrm{d}}$ & $512 \pm 19^{\mathrm{i}}$ & $27 \pm 2^{a, b}$ & $91 \pm 5^{\mathrm{d}, \mathrm{e}}$ \\
\hline whey permeate powder & $133 \pm 2^{\mathrm{f}}$ & $425 \pm 17^{j}$ & $26 \pm 3^{b}$ & $84 \pm 1$ e \\
\hline whey powder (demineralized) & $121 \pm 1^{\mathrm{g}}$ & $929 \pm 14^{\mathrm{f}}$ & $11 \pm 1^{\mathrm{d}}$ & $84 \pm 4^{\mathrm{e}}$ \\
\hline whey powder (non-demineralized) & $123 \pm 2^{g}$ & $834 \pm 16^{g}$ & $27 \pm 1^{\mathrm{a}, \mathrm{b}}$ & $180 \pm 9^{a, b}$ \\
\hline buttermilk powder & $173 \pm 2^{b}$ & $622 \pm 18^{h}$ & $27 \pm 2^{a, b}$ & $96 \pm 5^{d}$ \\
\hline \multicolumn{5}{|c|}{ Kefir B } \\
\hline control & $126 \pm 1 \mathrm{~g}$ & $391 \pm 10^{j}$ & $27 \pm 1^{a, b}$ & $83 \pm 4^{\mathrm{e}}$ \\
\hline MPC-80 & $163 \pm 14^{c}$ & $1251 \pm 12^{c}$ & $12 \pm 1^{\mathrm{d}}$ & $89 \pm 4^{\mathrm{d}, \mathrm{e}}$ \\
\hline WPC-70 & $121 \pm 1^{\mathrm{g}}$ & $857 \pm 14^{\mathrm{g}}$ & $11 \pm 1^{\mathrm{d}}$ & $78 \pm 4 \mathrm{e}$ \\
\hline rennet casein & $133 \pm 3^{f}$ & $1111 \pm 24^{\mathrm{d}}$ & $13 \pm 1^{\mathrm{d}}$ & $112 \pm 6^{c}$ \\
\hline sweet whey powder & $145 \pm 5^{\mathrm{e}}$ & $480 \pm 15^{i, j}$ & $29 \pm 2^{a}$ & $96 \pm 5^{d}$ \\
\hline whey permeate powder & $131 \pm 7^{\mathrm{f}, \mathrm{g}}$ & $419 \pm 23^{j}$ & $25 \pm 2^{b, c}$ & $79 \pm 4^{\mathrm{e}}$ \\
\hline whey powder (demineralized) & $136 \pm 5^{\mathrm{f}}$ & $1049 \pm 17^{\mathrm{e}}$ & $11 \pm 1^{\mathrm{d}}$ & $83 \pm 4^{\mathrm{e}}$ \\
\hline whey powder (non-demineralized) & $133 \pm 3^{f}$ & $907 \pm 20^{\mathrm{f}}$ & $26 \pm 2^{b}$ & $176 \pm 9^{b}$ \\
\hline buttermilk powder & $137 \pm 2^{\mathrm{f}}$ & $494 \pm 16^{\mathrm{i}, \mathrm{j}}$ & $24 \pm 2^{c}$ & $86 \pm 4$ d,e \\
\hline \multicolumn{5}{|c|}{ Kefir C } \\
\hline control & $130 \pm 1^{f, g}$ & $402 \pm 14^{j}$ & $26 \pm 2^{b}$ & $80 \pm 4^{e}$ \\
\hline MPC-80 & $184 \pm 9^{a}$ & $1420 \pm 17^{\text {a }}$ & $10 \pm 1^{\mathrm{d}}$ & $80 \pm 4^{e}$ \\
\hline WPC-70 & $185 \pm 10^{\mathrm{a}}$ & $1311 \pm 14^{b}$ & $12 \pm 1^{\mathrm{d}}$ & $83 \pm 4^{\mathrm{e}}$ \\
\hline rennet casein & $162 \pm 7^{c}$ & $1349 \pm 19^{b}$ & $13 \pm 1^{\mathrm{d}}$ & $105 \pm 5^{c, d}$ \\
\hline sweet whey powder & $151 \pm 5^{\mathrm{d}}$ & $500 \pm 15^{\mathrm{i}}$ & $30 \pm 2^{a}$ & $98 \pm 5^{\mathrm{d}}$ \\
\hline whey permeate powder & $141 \pm 1^{\mathrm{e}, \mathrm{f}}$ & $450 \pm 12^{j}$ & $25 \pm 2^{b, c}$ & $79 \pm 4^{\mathrm{e}}$ \\
\hline whey powder (demineralized) & $123 \pm 3 g$ & $950 \pm 22^{\mathrm{f}}$ & $11 \pm 1^{\mathrm{d}}$ & $83 \pm 4^{\mathrm{e}}$ \\
\hline whey powder (non-demineralized) & $133 \pm 3^{f}$ & $907 \pm 20^{f}$ & $28 \pm 2^{a}$ & $193 \pm 10^{\mathrm{a}}$ \\
\hline buttermilk powder & $143 \pm 3^{\mathrm{e}}$ & $516 \pm 10^{\mathrm{i}}$ & $24 \pm 2^{c}$ & $88 \pm 4^{\mathrm{d}}$ \\
\hline
\end{tabular}

${ }^{a-j}$ the same letter indices within the same column do not mean statistically significant differences at the significance level of 0.05 .

Considering the type of milk protein preparation added, the highest content of available lysine was recorded in the kefirs obtained from milk with WPC-70 or MPC-80 fermented with starter C (184 \pm 9 and $185 \pm 10 \mathrm{mg} / \mathrm{g}$ of protein, respectively), as well as in the samples obtained from milk with WPC-70 or buttermilk powder fermented with starter A (171 \pm 19 and $173 \pm 2 \mathrm{mg} / \mathrm{g}$ of protein, respectively). If the content of available lysine was expressed as the amount in $100 \mathrm{~g}$ of kefir samples, each added milk protein preparation increased the content, although in some cases this increase was found to be statistically insignificant. No relationship was found between the amount of available lysine and the total protein content. It can therefore be concluded that the available lysine concentration is influenced by the additive and type of milk protein preparation, as well as the proteolytic activity of the starter used for fermentation.

Available glycine content is an expression of protein digestibility, which was determined in this study by using the second method (Table 3). The digestibility of proteins in kefir samples enriched with various preparations of milk proteins, determined using this method, differed significantly from the results obtained with the first method, described above. It should be noted that the content of available glycine was statistically significantly influenced by the type of milk protein powder used $(p=0.0001)$, but not by the type of kefir starter used $(p=0.1198)$ or the $\mathrm{pH}$ of the kefir samples $(p=0.7791)$. The highest available glycine content in $100 \mathrm{~g}$ of kefir samples was found in the samples prepared with whey powder (non-demineralized) $(180 \pm 9,176 \pm 9$, and $193 \pm 10 \mathrm{mg} / 100 \mathrm{~g}$ of the product, respectively) as well as the samples prepared with rennet casein $(110 \pm 5,112 \pm 6$, and $105 \pm 5 \mathrm{mg} / 100 \mathrm{~g}$ of the product, respectively). In other cases, the content of available 
glycine was comparable to that in control samples or was about $10 \%$ higher. Expressing the content of available glycine in $1 \mathrm{~g}$ of protein showed that the addition of milk protein preparations did not increase or reduce the content compared to the control samples. Only for kefir $\mathrm{C}$ obtained from milk with the addition of sweet whey powder was the content found to be significantly higher than the control samples.

\section{Discussion}

In our experiments, the counts of both Lactococcus spp. and lactobacilli were detected at levels above 7 and $6 \log (\mathrm{CFU} / \mathrm{mL})$ in the kefir samples, respectively (Table 1). The obtained results confirm those shown by other researchers [3,23-26]. For instance, Montanuci et al. [27] reported that the addition of inulin did not affect the counts of Lactococcus spp. in the kefir samples. Magra et al. [28] reported that the number of Lactococcus spp. in kefir samples reduced due to the high acidity of kefir. In our study, we did not observe the lactococci population to be dependent on the $\mathrm{pH}$ of kefirs, at least at the stage of milk fermentation. As mentioned in the Introduction section, many researchers have shown that, compared to SMP, WPC significantly stimulates the growth of several strains of lactic acid bacteria [4]. However, we did not notice such an effect in the analyzed kefir samples for lactococci and lactobacilli.

Usually, fermentation is carried out until the kefir reaches a $\mathrm{pH}$ of 4.4-4.6, which takes from 16 to 24 h [2,26,29,30]. García Fontán et al. [23] described the 24-h fermentation process as the most effective for kefir production in the context of $\mathrm{pH}$ changes. In our experiments, we fermented milk for $24 \mathrm{~h}$ to analyze how the addition of different milk protein powders could affect the $\mathrm{pH}$ changes (Table 1 ). The typical $\mathrm{pH}$ of commercial kefirs ranges from 4.3 to 4.4 [2], which are comparable to the values measured in our research. However, it should be noted that our kefir samples contained added milk protein powders, and as we know, milk proteins have some buffering capacity and thus reduce the observed $\mathrm{pH}$ reduction rate $[4,29,31]$. This is probably the reason for the higher $\mathrm{pH}$ values (in the range of 4.4-5.2) observed in the samples prepared with milk protein powders compared to the control sample (mean $\mathrm{pH} 4.5$ ).

The acid gel formed during the fermentation of milk with lactic acid bacteria is a threedimensional protein matrix in which some other components of the milk base, including polysaccharides produced by the microflora of starter cultures, are trapped. Therefore, when analyzing the texture parameters of kefir prepared using lactic acid bacteria starters, it could be expected that the nature and relative proportions of different proteins play a significant role in determining the texture of the final product, which has already been shown by many researchers $[32,33]$. However, studies on the textural properties of kefir prepared with milk proteins are not numerous. The protein content in milk dedicated to the production of kefir can be increased by adding WPC or MPC, or possibly retentate, and caseinate. The use of such additives will have different effects on the protein composition of the dairy base, as the ratio of protein to total dry weight and that of whey proteins to caseins will change, which has a significant impact on the texture of the product. The effect of milk base, starter cultures, and process parameters on texture of fermented milk, based on the example of yogurt, were discussed in detail in reference [33]. The exact influence of these proportions on the texture of kefirs is not easy to estimate, given the additional influence of the starter culture. Very few studies have examined the effects of the ratio of whey protein to casein on the texture of fermented milk beverages without changing the proportion of total protein in the dry matter of processing milk [33]. In our research, we added the same amount of milk protein powders to the processing milk, but these powders were characterized by different protein content and different composition of milk proteins, due to which the kefir samples obtained differed in the total protein content and the proportion of proteins from whey to casein as well as the proportion of total whey proteins. Milk powders or milk protein concentrate powders addition, which are usually applied in fermented milks production, gives the proportion of proteins to total solid content and the proportion of whey protein to casein content close to that of native milk. 
In contrast, whey protein powders and whey protein concentrates are an important source of whey proteins, with a variable content of other dairy ingredients (e.g., mineral salts) depending on the degree of purification of the preparations (e.g., demineralized whey powders contain about half as much ash than non-demineralized whey powders whey powders and salt content can alter the results). Moreover, it must be remembered that the effect of the addition of a milk base on milk proteins is strongly dependent on the heat treatment of milk and the added milk powder [33]. For example, rennet casein powder contains denatured casein proteins, so the role of these proteins in acid clot formation is not significant. This is probably why the hardness as well as the adhesiveness of the kefir samples prepared with milk protein powders depended on the type of milk protein powder added. These factors, individually and in combination with the effects of using different starter cultures, led to a difficult interpretation of the results obtained by us. We have also shown that the tested texture parameters were strongly influenced by the type of kefir starter culture used. It should be assumed that the decisive factor in this case is the qualitative and quantitative microorganism composition of the starter culture. Many scientists have proven in their research that the microflora can produce exopolysaccharides (EPS), which significantly affects the texture of fermented milk [34].

The WHC of kefir refers to its tendency to retain water or its resistance to phase separation. However, it should be remembered that the centrifugation test used in our experiments may give results irrelevant for syneresis under normal storage conditions. This is because the mechanical stability of the protein network is investigated more under the influence of $G$ forces than under normal storage conditions [33]. Many authors [34-37] reported that the higher the milk protein content, the higher the WHC. We also showed in this study that the addition of milk powders increased the WHC value of kefirs. WacherRodarte et al. [34] showed that the use of microflora influenced the structural parameters and balanced the effect of dry matter enrichment on the WHC value. However, the type of protein added to the milk plays an important role. Increasing the concentration of casein enhances the interaction between its molecules. In this case, the casein chains become shorter, the pore size in the gel becomes smaller, and the gel density increases. In addition, an increased concentration of whey proteins added leads to an increase in the WHC value [35,36,38,39]. This was also confirmed by Guzman-Gonzalez et al. [40,41] with the addition of WPC to yogurt. Furthermore, Aguilera and Kessler [35] and Harwalkar and Kalab [36] confirmed that yogurt $\mathrm{pH}$ has a significant effect on WHC.

The available lysine content is a measure of the nutritional value of the milk protein [42]. The content of lysine in food and its availability are extremely important because it is an essential amino acid that is often found in relatively small amounts in diet [43-45]. Irigoyen et al. [24] determined the content of available lysine in kefir samples obtained in laboratory conditions at a level of $41 \mathrm{mg} / 100 \mathrm{~g}$ of product; for comparison, in $100 \mathrm{~g}$ of commercial yogurt, there was an average of $113 \mathrm{mg}$ of available lysine (similar to the content achieved in our experiments). The decrease in the available lysine concentration in milk may be due to thermal treatment (e.g., pasteurization) [42]. Lysine is susceptible to modifications occurring during the processing or long-term storage of food samples. For example, it can react with lactose or other substances and form nutritionally inaccessible (nonreactive) derivatives [44,45]. Hence, the addition of milk protein preparations seems an interesting solution to increase the level of available lysine. Our experiments showed that this can be achieved in kefir with the use of WPC-80 or WPC-70. It is also important to select an appropriate starter culture for the fermentation of milk into kefir because the enzymatic activity of the microflora present in the starter determines the amount of lysine in the final product $[46,47]$. Furthermore, Simsek et al. [48] showed that fermentation had no significant effect on kefir proteins obtained from inulin-enriched goat milk. Using sodium dodecyl sulfate-polyacrylamide gel electrophoresis, researchers found that raw milk, heated milk, and kefir showed comparable protein profiles.

We can, however, suggest that the effects of fermentation on the quality of milk proteins depend on the method used for determining their digestibility. Kopf-Bolanz et al. [49] 
claimed that fermentation improves digestibility in products due to partial degradation of casein proteins [49]. It should be noted that these authors used colloidal Coomassie blue staining and identified proteins by liquid chromatography-mass spectrometry after trypsin digestion. Our experiments on protein digestibility using two assay methods showed different results. From the results of the analytical method used, we can conclude that the starter culture has a significant effect on the availability of selected amino acids (available lysine and glycine), and thus the digestibility of milk proteins, as well as that milk protein preparations have a different influence on the quality of protein in kefir.

\section{Conclusions}

The rules of kefir production vary worldwide, while the recipe and technological parameters significantly affect the quality features of the final product. The quality features are one of factors that influence customer's acceptance on product, including fermented milks such as kefir. Our study showed that various milk protein preparations can be successfully used as additives for milk intended for kefir fermentation. Although the influence of these additives on the quality parameters tested by us was significant, it was not clear. The addition of various forms of milk proteins, including MPC, WPC, demineralized or non-demineralized whey, sweet whey, whey permeate, rennet casein, and buttermilk powders, had an impact on the population of lactic acid bacteria in the obtained kefirs, and therefore on the final $\mathrm{pH}$ of the kefirs. However, the type of starter culture used to obtain these kefirs also influenced the microflora, as well as the final total protein content in kefirs resulting from the addition of milk protein preparations with different amounts of proteins. Depending on their type, and the starter culture used, milk protein preparations increased the WHC of kefirs, as well as changed their hardness and adhesiveness. In most cases, the investigated quality parameters of kefirs differed depending on both the type of milk protein powder added and the starter culture used. This means that when using the additives of milk protein preparations tested by us in industrial production, the starter culture should be carefully selected to obtain kefir with the desired and expected quality parameters, including hardness.

Enrichment of milk with milk protein preparations resulted in a change in the digestibility of proteins in kefir. However, proper selection of the method is important to investigate the digestibility of proteins in the final kefir. We compared two methods applied for determining the digestibility of milk proteins using in vitro enzymatic digestion. The principle of the first method is to determine the content of free lysine which in turn is used to assess the digestibility of protein. The principle of the second method consists in subjecting the test samples to a two-step enzymatic hydrolysis process followed by the determination of the concentration of available glycine. An increase in the amount of available lysine as well as available glycine was observed. However, kefirs prepared with different additives in the milk protein preparations exhibited different levels of these amino acids. In the case of the availability of lysine, we observed differences between kefirs obtained using different starter cultures. Testing the digestibility of kefir proteins by determining the available glycine in vitro showed different results than those observed with the determination of the available lysine in vitro. It turned out that the digestibility of milk proteins tested using the enzymatic digestion method in vitro indicated the effect of the addition of milk protein preparations and the type of starter culture used on the protein quality of kefirs.

Author Contributions: Conceptualization, M.Z. and R.H.; methodology, M.Z. and A.C.; formal analysis, M.Z., R.H., and A.C.; investigation, M.Z., R.H., and A.C.; data curation, M.Z.; writingoriginal draft preparation, M.Z., R.H., and A.C.; writing-review and editing, M.Z. All authors have read and agreed to the published version of the manuscript.

Funding: This work was supported by a grant from Warsaw University of Life Sciences-WULSSGGW.

Institutional Review Board Statement: Not applicable. 
Informed Consent Statement: Not applicable.

Data Availability Statement: Data sharing not applicable.

Conflicts of Interest: The authors declare no conflict of interest.

\section{References}

1. Witthuhn, R.C.; Schoeman, T.; Britz, T.J. Characterisation of the microbial population at different stages of Kefir production and Kefir grain mass cultivation. Int. Dairy J. 2005, 15, 383-389. [CrossRef]

2. Dogan, M. Rheological behaviour and physicochemical properties of kefir with honey. J. Consum. Prot. Food Saf. 2011, 6, 327-332. [CrossRef]

3. Güzel-Seydim, Z.B.; Twyffels, J.; Seydim, A.C.; Greene, A.K. Turkish kefir and kefir grains: Microbial enumeration and electron microscobic observation. Int. J. Dairy Technol. 2005, 58, 25-29. [CrossRef]

4. Tratnik, L.; Bozanic, R.; Herceg, Z.; Drglic, I. The quality of plain and supplemented kefir from goat's and cow's milk. Int. J. Dairy Technol. 2006, 59, 40-46. [CrossRef]

5. Otles, S.; Cagindi, O. Kefir: A Probiotic Dairy-Composition. Pak. J. Nutr. 2003, 2, 54-59. [CrossRef]

6. Karagozlu, C.; Unal, G.; Akalin, A.S.; Akan, E.; Kinik, O. The effects of black and green tea on antioxidant activity and sensory characteristics of kefir. Agro Food Ind. Hi Tech 2017, 28, 77-80.

7. Lagouri, V.; Dimitreli, G.; Kouvatsi, A. Effects of Greek Pomegranate Extracts in the Antioxidant Properties and Storage Stability of Kefir. Curr. Bioact. Compd. 2019, 15, 437-441. [CrossRef]

8. Aiello, F.; Restuccia, D.; Spizzirri, U.G.; Carullo, G.; Leporini, M.; Loizzo, M.R. Improving Kefir Bioactive Properties by Functional Enrichment with Plant and Agro-Food Waste Extracts. Fermentation 2020, 6, 83. [CrossRef]

9. Savoie, L.; Gauthier, S.F. Dialysis cell for the in vitro measurement of protein digestibility. J. Food Sci. 1986, 51, 494-495. [CrossRef]

10. Yeoung, A.K.; Barbeau, W.E. Evaluation of SDS-PAGE method for estimating protein digestibility. J. Food Sci. 1991, 56, 1082-1086. [CrossRef]

11. Hęś, M.; Waszkowiak, K.; Szymandera-Buszka, K. The effect of iodine salts on lipid oxidation and changes in nutritive value of protein in stored processed meats. Meat. Sci. 2012, 92, 139-143. [CrossRef]

12. Pokorska-Lis, G.; Tokarz, A.; Dębek, P. In Vitro enzymatic hydrolysis of milk and dairy products proteins. Brom. Chem. Toksykol. 2012, 45, 573-574, (Abstract in English).

13. Hoppe, A.; Jung, S.; Patnaik, A.; Zeece, M. Effect of high pressure treatment on egg white protein digestibility and peptide products. Innov. Food Sci. Emerg. Technol. 2013, 17, 54-62. [CrossRef]

14. Rui, X.; Zhang, Q.; Huang, J.; Li, W.; Chen, X.; Jiang, M.; Dong, M. Does lactic fermentation influence soy yogurt protein digestibility: A comparative study between soymilk and soy yogurt at different pH. J. Sci. Food Agric. 2018, 99, 861-867. [CrossRef]

15. International Organization for Standardization. ISO 6887-5:2020. Microbiology of the Food Chain-Preparation of Test Samples, Initial Suspension and Decimal Dilutions for Microbiological Examination-Part 5: Specific Rules for the Preparation of Milk and Milk Products; International Organization for Standardization: Geneve, Switzerland, 2020.

16. International Organization for Standardization. ISO 15214:1998. Microbiology of Food and Animal Feeding Stuffs—Horizontal Method for the Enumeration of Mesophilic Lactic Acid Bacteria-Colony-Count Technique at 30 Degrees C; International Organization for Standardization: Geneve, Switzerland, 1998.

17. International Organization for Standardization. ISO 6611:2004. Milk and Milk Products_Enumeration of Colony-Forming Units of Yeasts and/or Moulds - Colony-Count Technique at 25 Degrees C; International Organization for Standardization: Geneve, Switzerland, 2004.

18. Ziarno, M.; Zareeba, D. The effect of the addition of microbial transglutaminase before the fermentation process on the quality characteristics of three types of yogurt. Food Sci. Biotechnol. 2020, 29, 109-119. [CrossRef] [PubMed]

19. International Organization for Standardization. ISO 8968-4:2016. Milk and Milk Products—Determination of Nitrogen Content-Part 4: Determination of Protein and Non-Protein Nitrogen Content and True Protein Content Calculation (Reference Method); International Organization for Standardization: Geneve, Switzerland, 2016.

20. Hall, R.J.; Trinder, N.; Givens, D.I. Observations on the use of 2,4,6-trinitrobenzenesulphonic acid for the determination of available lysine in animal protein concentrates. Analyst 1973, 98, 673-686. [CrossRef] [PubMed]

21. Pokorska-Lis, G.; Woźniak, J.; Olędzka, R. Azotany i azotyny w enzymatycznej hydrolizie białka. Brom. Chem. Toksykol. 1995, 28, 107-111, (Abstract in English).

22. Jacobs, S. Determination of nitrogen in proteins by means of indanetrione hydrate. Nature 1959, 183, 262. [CrossRef]

23. García Fontán, M.C.; Martínez, S.; Franco, I.; Carballo, J. Microbiological and chemical changes during the manufacture of Kefir made from cows' milk, using a commercial starter culture. Int. Dairy J. 2006, 16, 762-767. [CrossRef]

24. Irigoyen, A.; Arana, I.; Castiella, M.; Torre, P.; Ibanez, F.C. Microbiological, physicochemical, and sensory characteristics of kefir during storage. Food Chem. 2005, 90, 613-620. [CrossRef]

25. Loretan, T.; Mostert, J.F.; Viljoen, B.C. Microbial flora associated with South African household kefir. S. Afr. J. Sci. 2003, 99, 92-94.

26. Wszolek, M.; Tamime, A.; Muir, D.; Barclay, M. Properties of kefir made in Scotland and Poland using bovine, caprine and ovine milk with different starter cultures. Lebensm. Wiss. Technol. 2001, 34, 251-261. [CrossRef] 
27. Montanuci, F.D.; Pimentel, T.C.; Garcia, S.; Prudencio, S.H. Effect of starter culture and inulin addition on microbial viability, texture, and chemical characteristics of whole or skim milk kefir. Food Sci. Technol. 2012, 32, 580-865. [CrossRef]

28. Magra, T.I.; Antoniou, K.D.; Psomas, E.I. Effect of milk fat, kéfir grain inoculum and storage time on the flow properties and microbiological characteristics of kefir. J. Text. Stud. 2012, 43, 299-308. [CrossRef]

29. Ertekin, B.; Guzel-Seydim, Z.B. Effect of fat replacers on kefir quality. J. Sci. Food Agric. 2010, 90, 543-548. [CrossRef] [PubMed]

30. Simona, E.; Beshkova, D.; Angelov, A.; Hristozova, T.; Frengova, G.; Spasov, Z. Lactic acid bacteria and yeasts in kefir grains and kefir made from them. J. Ind. Microbiol. Biotechnol. 2002, 28, 1-6. [CrossRef]

31. Amatayakul, T.; Halmos, A.L.; Sherkat, F.; Shah, N.P. Physical characteristics of yogurts made using exopolysaccharideproducing starter cultures and varying casein to whey protein ratios. Int. Dairy J. 2006, 16, 40-51. [CrossRef]

32. Modler, H.; Larmond, M.; Lin, C.; Froelich, D.; Emmons, D.B. Physical and sensory properties of yogurt stabilized with milk proteins. J. Dairy Sci. 1983, 66, 422-429. [CrossRef]

33. Sodini, I.; Remeuf, F.; Haddad, S.; Corrieu, G. The relative effect of milk base, starter, and process on yogurt texture: A review. Crit. Rev. Food Sci. Nutr. 2004, 44, 113-137. [CrossRef]

34. Wacher-Rodarte, C.; Galvan, M.V.; Farres, A.; Gallardo, F.; Marshall, V.M.E.; Garcia-Garibay, M. Yogurt production from reconstituted skim milk using different polymer and non polymer forming starter cultures. J. Dairy Res. 1993, 60, 247-254. [CrossRef]

35. Aguilera, J.M.; Kessler, H.G. Properties of mixed and filledtype dairy gels. J. Food Sci. 1989, 54, 1213-1217. [CrossRef]

36. Harwalkar, V.R.; Kalab, M. Relationship between microstructure and susceptibility to syneresis in yogurt made from reconstituted nonfat dry milk. Food Microstruct. 1986, 5, 287-294.

37. Omar, M.M.; Abou El-Nour, A.M. Rheological properties of yogurt enriched with whole milk protein. Egypt. J. Dairy Sci. 1998, 26, 77-88.

38. Guirguis, N.; Broome, M.C.; Hickey, M.W. The effect of partial replacement of skim milk powder with whey protein concentrate on the viscosity and syneresis of yogurt. Aust. J. Dairy Technol. 1984, 39, 33-35.

39. Guinee, T.P.; Mullins, C.G.; Reville, W.J.; Cotter, M.P. Physical properties of stirred-curd unsweetened yogurts stabilized with different dairy ingredients. Milchwissenschaft 1995, 50, 196-200.

40. Guzman-Gonzalez, M.; Morais, F.; Pamos, M.; Amigo, L. Influence of skimmed milk concentrate replacement by dry dairy products in a low fat set-type yogurt model system. I: Use of whey protein concentrates, milk protein concentrates and skimmed milk powder. J. Sci. Food Agric. 1999, 79, 1117-1122. [CrossRef]

41. Guzman-Gonzalez, M.; Morais, F.; Amigo, L. Influence of skimmed milk concentrate replacement by dry dairy products in a lowfat set-type yogurt model system. Use of caseinates, co-precipitate and blended dairy powders. J. Sci. Food Agric. 2000, 80, 433-438. [CrossRef]

42. Silvestre, D.; Ferrer, E.; Gayá, J.; Jareño, E.; Miranda, M.; Muriach, M.; Romero, F.J. Available lysine content in human milk: Stability during manipulation prior to ingestion. Biofactors 2006, 26, 71-79. [CrossRef]

43. Rutherfurd, S.M.; Moughan, P.J. Digestible reactive lysine in selected milk-based products. J. Dairy Sci. 2005, 88, 40-48. [CrossRef]

44. Hurrell, R.F.; Carpenter, K.J. The estimation of availablelysine in foodstuffs after Maillard reactions. Prog. Food Nutr. Sci. 1981, 5, 159-176.

45. Moughan, P.J. Amino acid availability: Aspects of chemicalanalysis and bioavailability methodology. Nutr. Res. Rev. 2003, 16, 127-141. [CrossRef] [PubMed]

46. Vass, A.; Szakaly, S.; Schmidt, P. Experimental study of the nutritional biological characters of fermented milks. Acta Med. Hung. 1983, 41, 157-161.

47. Dallas, D.C.; Citerne, F.; Tian, T.; Silva, V.; Kalanetra, K.M.; Frese, S.A.; Robinson, R.C.; Mills, D.A.; Barile, D. Peptidomic analysis reveals proteolytic activity of kefir microorganisms on bovine milk proteins. Food Chem. 2016, 197, 273-284. [CrossRef] [PubMed]

48. Simsek, S.; Sánchez-Rivera, L.; El, S.N.; Karakaya, S. Characterisation of in vitro gastrointestinal digests from low fat caprine kefir enriched with inulin. Int. Dairy J. 2017, 75, 68-74. [CrossRef]

49. Kopf-Bolanz, K.A.; Schwander, F.; Gijs, M.; Vergères, G.; Portmann, R.; Egger, L. Impact of milk processing on the generation of peptides during digestion. Int. Dairy J. 2014, 35, 130-138. [CrossRef] 